\title{
Tessera: Scalable, Shade Robust Module
}

\author{
Anna J. Carr, Koen de Groot, Mark J. Jansen, Evert Bende, John van Roosmalen, Lars Okel, Wilma \\ Eerenstein \\ ECN Solar Energy, Petten, 1755 ZG, The Netherlands \\ Rudi Jonkman, Robert van der Sanden \\ Heliox BV, Best, 5684 PX, The Netherlands \\ Jan Bakker, Bart de Gier \\ Eurotron BV, Bleskensgraaf, $2971 \mathrm{VL}$, The Netherlands \\ Adriaan Harthoorn \\ Stafier Solar Systems BV, Zevenaar, 6902 PC, The Netherlands
}

\begin{abstract}
This paper describes the development and output measurements on a new shade robust module, named the Tessera module. This module uses a novel electrical configuration, comprised of shade independent blocks protected by in-laminate diodes, with a mixture of series and parallel connections. By using ECN's existing back contact technology [1], no significant additional manufacturing costs occur. The design, method and manufacturing technology will be explained. The module leads to an increased annual output in case of shading and an increase in system safety due to lower heat dissipation: of $40^{\circ} \mathrm{C}$ instead of $130^{\circ} \mathrm{C}$ compared to standard diodes, and reduced failure of components. Annual yield has been calculated showing significant gains.
\end{abstract}

Index Terms - annual yield, micro-inverter, PV module, shade, shade robust, shade linear, plug and play.

\section{INTRODUCTION}

Standard PV systems composed of several modules in series and a string inverter can experience significant yield losses in case of shading [2]. Because only one current can run through series connected modules, all of the modules carry the current of the lowest performing module unless the shaded section is bypassed by a diode, leading to significant power losses. A solution on the system level are micro-inverters [3]. Microinverters allow modules to be connected to the power net in parallel, not influencing each other.

However, in this paper a solution is presented to increase the output on the module level when shade is present. It consists of several shade independent blocks, each protected by in-laminate diodes. The cells within the blocks are connected in series, whereas the block are connected in parallel leading to a easily scalable system which maintains a constant voltage and shows an almost linear shadow response. Such a module has the following advantages:

- No additional manufacturing costs

- The inverter specifications are easier compared to standard modules due to the module output (Vmpp and Impp)
- The heat dissipation in the diodes is significantly reduced. This lowers risks of damage to the diodes, the junction box or the laminate due to a local hotspot

- Increased yield when shade is present

- Application of modules in locations where standard panels would not be economical. This leads to improved aesthetics and 'plug and play' installation, as no shade analysis is required by the installer.

The concept of such a shade robust module was presented in 2014 [4]. The current work describes the new module design and layout, including in-laminate diode processing and reliability, shade response measurements and annual yield calculations on a system level.

\section{MODULE CONCEPT}

In a standard module three strings of 20 cells are interconnected in series and connected to a bypass diode. The strings typically carry a curent of $8 \mathrm{~A}$, and high efficiency modules move towards $9 \mathrm{~A}$. When one or more cells are shaded heavily, the current of the entire string will pass through the bypass diode, leading to a significant output reduction and significant heating in the bypass diode. This can be an issue, particularly in BIPV.

The shade robust Tessera module decribed in this paper will be standard size (60 cells of $156 \mathrm{~mm}$ each), around 1 x 1.6 meters. Inside the module there are several shade independent blocks. The shape of the blocks is optimised such that the chance of shade leading to activation of the diode is minimised. The shade independent blocks consist of a number of sub-cells which are cut from a standard $156 \mathrm{~mm}$ cell using laser scribing. The sub-cells are connected in series and bypassed by an in-laminate diode. Hence, smaller 'pixels' are created and only the pixel is lost when shaded and not $1 / 3^{\text {rd }}$ of the module. 


\section{$42^{\text {nd }}$ IEEE Photovoltaic Specialists Conference, June 14-19, 2015, New Orleans, USA}

The solar cells are back contact cells [1,5]. This allows interconnection via a conductive backsheet, and integrating the diodes, using an electrically conductive adhesive. The adhesive dots can all be printed at once using stencil printing and the sub-cells are placed using a pick-and-place system. A photograph of the conductive backsheet foil with a bypass diode and a prototype module [6,7] is shown in Fig. 1.

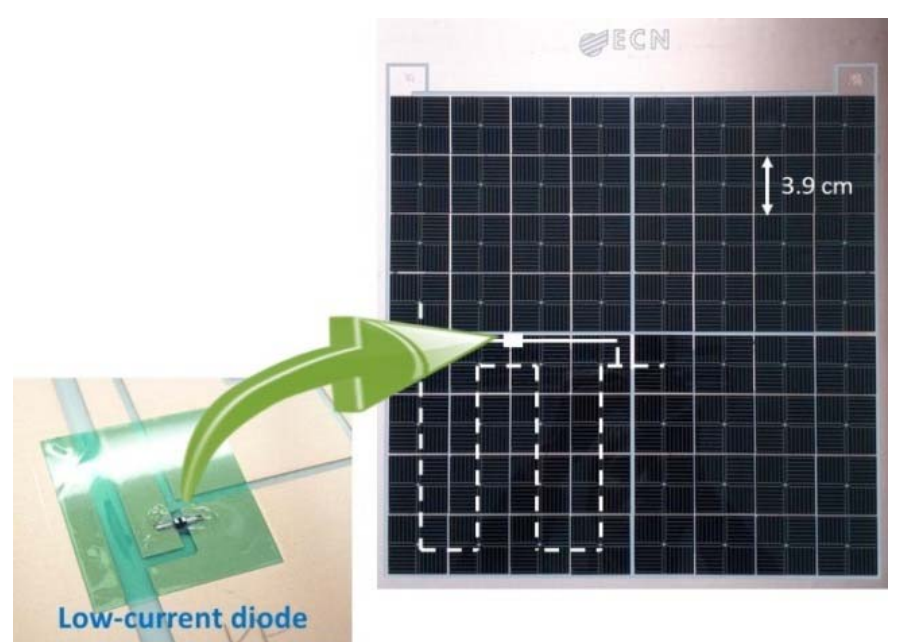

Fig. 1 Foil and prototype module with interconnection pattern of the sub cells as well as the diodes $[7,8]$.

These sub-cells are grouped in sets of 64 (4 standard $156 \mathrm{~mm}$ cells) as shown in Fig. 1. These 64 cell units form the building blocks of the shade robust module, each having a Voc of around $40 \mathrm{~V}$ and an Isc of $0.6 \mathrm{~A} .15$ of these blocks are connected in parallel to produce the full size Tessera module.

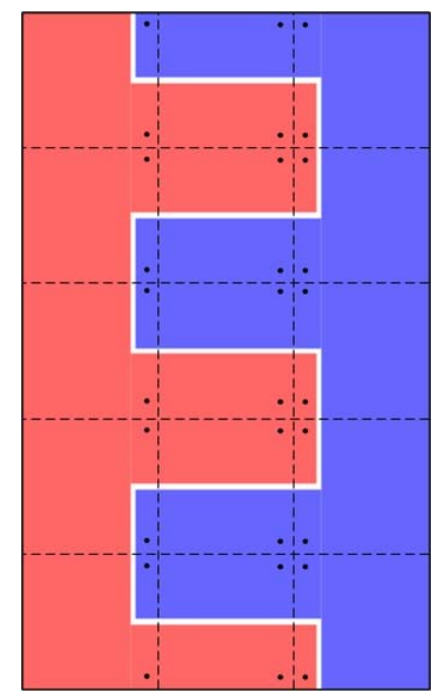

Fig. 2. Tessera interconnection conductive back sheet design, 15 building blocks connected in parallel. The two colours represent the two polarities. Each building block: Isc $=0.6 \mathrm{~A}$, Voc $=40 \mathrm{~V}$, Total Module: Isc $=9 \mathrm{~A}, \mathrm{Voc}=40 \mathrm{~V}$. [9].
The conductive back sheet foil used in back contact modules allow for greater flexibility in the electrical design of modules, Fig. 2. shows the foil design, [9], made for the parallel connection of the building blocks. The blue and red areas represent the two polarities, and each block has both positive and negative contacts. This allows great flexibility in design as any combination of these blocks can be connected in parallel, keeping the voltage constant, and scaling the current in multiples of $0.6 \mathrm{~A}$, making inverter design much simpler, and reducing inverter losses due to low maximum power point voltages.

This manufacturing method is the same as for standard back contact modules for which a fully automated production process is available [8] and independent of the exact size and nr. of sub-cells and diodes. The process will be adapted to include handling of smaller cells and integration of the diodes into the module manufacturing process.

A matching inverter is under development, allowing direct $\mathrm{DC}$ to AC conversion and hence no DC cabling and plug and play installation.

\section{EXPERIMENTAL}

\section{A. Module Manufacture}

Prototype modules have been made and the results reported previously [4]. The full size modules will be made using back contact foil based technology on a production line of Eurotron B.V. For the production all standard components for an MWT based back contact module [5,8] are used except for the in laminate diodes. For the in-laminate diodes several possibilities exist. Either commercial diodes can be applied, or small pieces of solar cell. The diodes are placed and interconnected on the back sheet (in reserved places) the same way as the cells. The best diode type will be selected for large scale manufacturability, based on the following criteria:

- ease of handling

- ease of interconnection

- reliability

- low temperature dissipation when active

Preliminary measurements of active diode temperatures have been made on both standard junction boxes and on our in-laminate diodes, to quantify the expected operating temperatures. Current was applied to the diodes and temperature measured with thermocouples. The standard diodes were operated at $9 \mathrm{~A}$, and the in-laminate diodes at $600 \mathrm{~mA}$.

\section{B. Output measurements for different shade cases}

To determine the shade performance of the Tessera module, we have used the PASAN flash tester (class AAA) to measure the 64 cell building blocks at standard test conditions, (STC), and then extrapolate these results to calculate the performance 
of a full size Tessera module. Using a method described previously [7], the building block module was measured at 15 specific locations on a $6 \times 10$ cell grid, representing a full size module, while being subjected to different partial shade cases.

The shade cases were pole, dormer and tree shade, Fig. 3. Using these measurements we have constructed the IV curves of a full size Tessera module, by combining the 15 measurements in parallel, and compared these with the IV curves of a conventional 60 cell module measured under the same shade conditions.
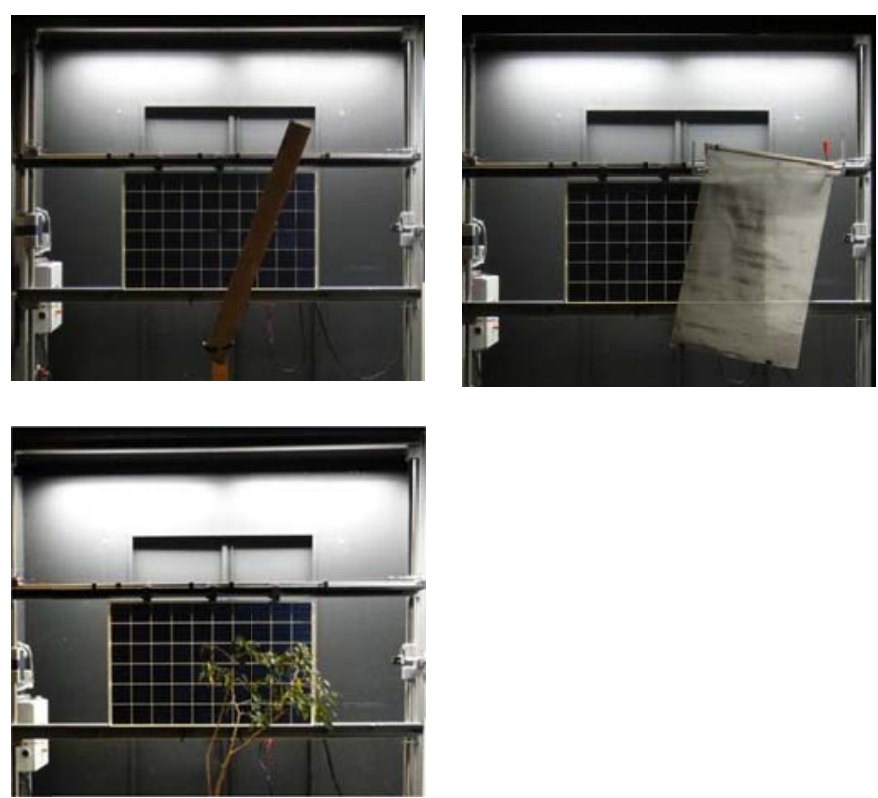

Fig. 3. Measurement set up for the three shade cases. Pole, Dormer and Tree

\section{Annual yield calculations}

The module annual energy yield has been calculated and compared to conventional modules using PVsyst 6 [10]. Herein a 3D-model of a PV system is created, and in front of it a shade casting object is placed. PVsyst calculates the module annual energy yield for the given system, location and shading scene.

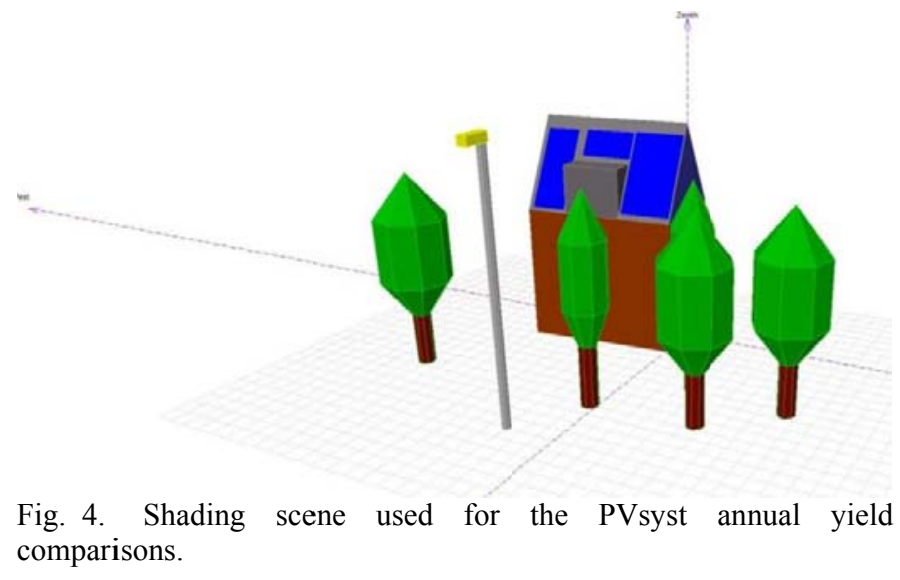

The system studied is a $4.7 \mathrm{~kW}$ system, made up of $18260 \mathrm{~W}$ modules, with each module connected to a micro-inverter. The site is defined as Amsterdam, with an orientation and tilt angle of $5^{\circ}$ East of South and $60^{\circ}$ respectively.

Unlike the static STC tests used to quantify the shade performance and shade linearity, these simulations represent a real operating system in the field, and calculate the total system performance for each hour over an entire year. They include all the combinations of irradiance and temperature that could be expected in a typical meteorological year for the given location and the performance and interaction of the inverters.

\section{RESULTS AND DISCUSSION}

\section{A. Temperature of diodes}

The diode temperature rises when the diode is conducting current. Junction boxes in standard modules are designed not to exceed the diodes maximum junction temperature. This, however, can still lead to significant temperature rises, as shown in Fig. 5. The temperature in this standard junction box rises up to $136^{\circ} \mathrm{C}$. These high diode case temperatures lead to local laminate temperature rise, reduced laminate life time expectancy and reduced actual module performance by cell temperature difference.

For in laminate diodes the first, preliminary, temperature measurements show values of $35-45^{\circ} \mathrm{C}$ diode case temperature. At about $600 \mathrm{~mA}$ test current and $21^{\circ} \mathrm{C}$ ambient temperature. Partly due to the MWT-back sheet spreading the heat of the diode. 


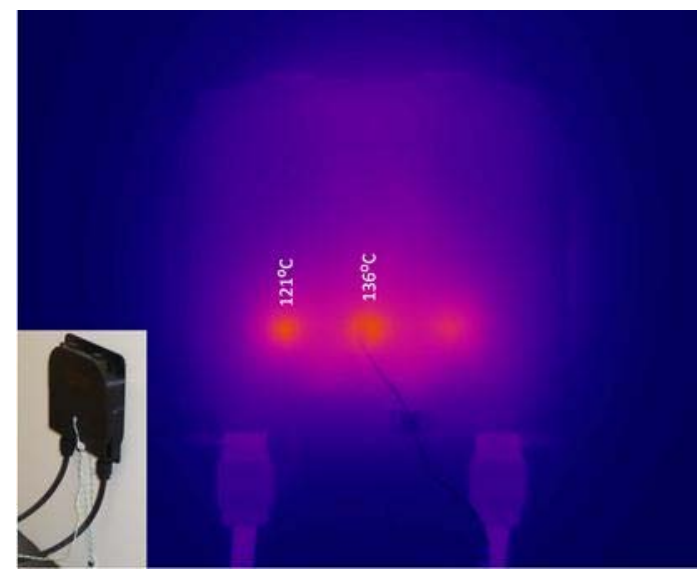

Fig. 5. Diode case in a temperature rising up to $136^{\circ} \mathrm{C}$ within a junction box on a standard PV laminate, through which $9 \mathrm{~A}$ has been applied for $1 \mathrm{hr}$. Ambient temperature is $21^{\circ} \mathrm{C}$.

\section{B. Results of different shade cases}

Through the measurements and methods described earlier for the different shade cases we have calculated the shade performance and shade linearity of the Tessera module and compared it with a standard module. As these tests are performed in a solar simulator and there is no diffuse light present and the shade can have a more extreme effect than in a real system.

The shade performance has previously been defined as the ratio of MPP power under shadow, and nominal MPP at standard test conditions, and the shade linearity relates the power output of the module under shade to that of an ideal fully shade-linear module under shade [7]. A module with perfect $100 \%$ shade linearity with an $\mathrm{x} \%$ sized shade will only lose $\mathrm{x} \%$ of its power.

The results in table one show that the Tessera module has a very high shade linearity compared to a standard 3 string module. Fig. $6 \&$ Fig. 7 show the current-voltage and powervoltage curves of the two modules for the extreme case of the pole shade.

TABLE I

RESULTS OF SHADING CASES

\begin{tabular}{|c|c|c|c|c|}
\hline \multirow{2}{*}{$\begin{array}{c}\text { Shadow } \\
\text { Type }\end{array}$} & \multicolumn{3}{|c|}{$\begin{array}{l}\text { Shade } \\
\text { Performance }\end{array}$} & \multicolumn{2}{l|}{ Shade Linearity } \\
\cline { 2 - 5 } & $\begin{array}{l}\text { Std. } \\
\text { Module } \\
(\%)\end{array}$ & $\begin{array}{l}\text { Tessera } \\
(\%)\end{array}$ & $\begin{array}{l}\text { Std. } \\
\text { Module } \\
(\%)\end{array}$ & $\begin{array}{l}\text { Tessera } \\
(\%)\end{array}$ \\
\hline Pole & 17 & 67 & 20 & 76 \\
\hline Dormer & 26 & 64 & 38 & 92 \\
\hline Tree & 53 & 73 & 66 & 92 \\
\hline
\end{tabular}

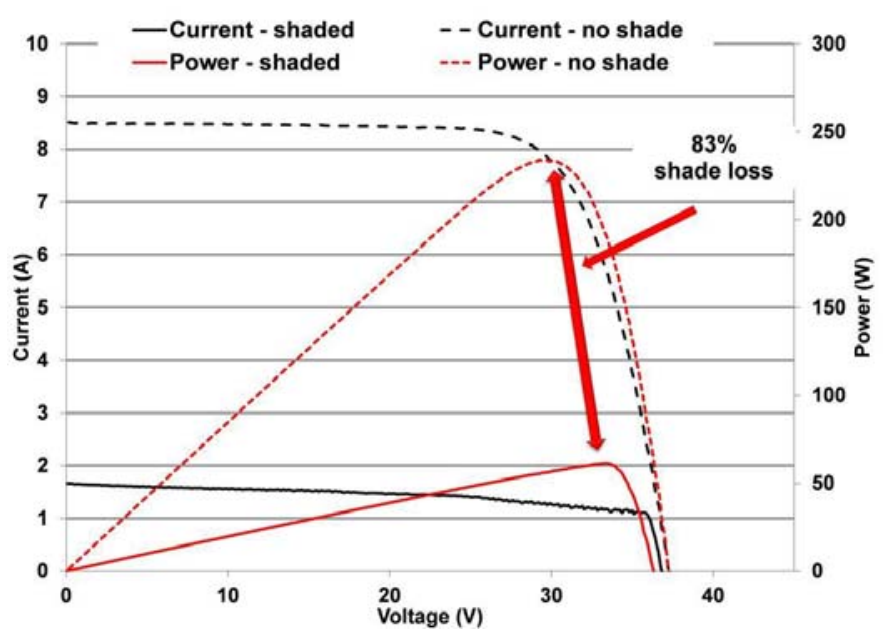

Fig. 6 Pole shade: Standard module - Current -Voltage and Power Voltage curves with and without shading - the standard module experiences an $83 \%$ loss in output (shadow performance of $17 \%$ ) for the pole shade.

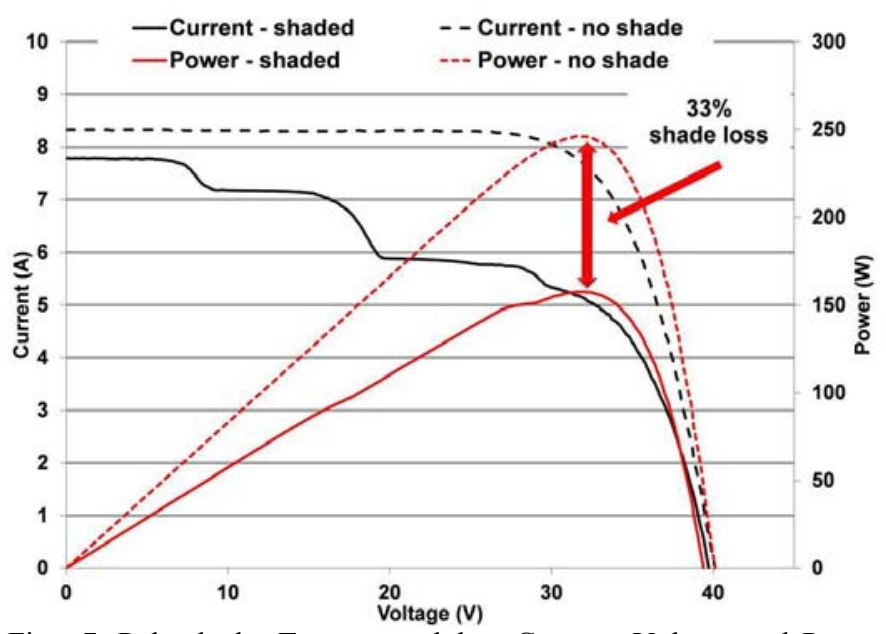

Fig. 7. Pole shade: Tessera module - Current -Voltage and Power Voltage curves with and without shading - the Tessera module experiences a $33 \%$ loss in output (shadow performance of $67 \%$ ) for the pole shade.

\section{Annual Yield Simulation Results}

The effect on annual yield on system level depends very strongly on the size, 3D effect and intensity of a particular shade. Using the shading scene in Fig. 4, the annual yield of a system of standard modules compared to Tessera modules has been computed.

The Tessera module has been carefully defined in PVsyst and the detailed electrical shading [10] has been used in calculating the annual yield for both systems. The Tessera module has an annual energy gain of $4 \%$ over the standard module for this system, location and shading scene as seen in TABLE II. A 4\% relative gain in energy yield can be equated with a near $1 \%$ absolute gain in module efficiency, to obtain 
the same annual electricity production one needs a $20.8 \%$ efficient module instead of a $20 \%$ efficient.

TABLE II

RESULTS OF ANNUAL YIELD AND SHADING LOSSES

\begin{tabular}{|c|c|c|c|}
\hline System & $\begin{array}{c}\text { No Shade } \\
(\mathrm{kWh})\end{array}$ & $\begin{array}{c}\text { Shade } \\
(\mathrm{kWh})\end{array}$ & $\begin{array}{c}\text { Loss } \\
(\%)\end{array}$ \\
\hline Standard & 4601 & 4115 & 11 \\
\hline Tessera & 4614 & 4279 & 7 \\
\hline $\begin{array}{c}\text { Tessera gain } \\
(\%)\end{array}$ & 0 & 4 & \\
\hline
\end{tabular}

The $4 \%$ annual yield gain is an average value calculated over the whole year, and this includes all the hours where there is no shading on the system. In our specific system scene we have seen that at certain times or hours during the year the gains are significantly higher than the $4 \%$ annual yield gain. Two hours have been chosen to illustrate this. They are: the $11^{\text {th }}$ of January between 11:00 and 12:00 and the $24^{\text {th }}$ of March between 16:00 - 17:00.

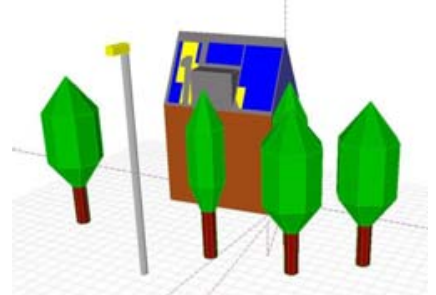

(a)

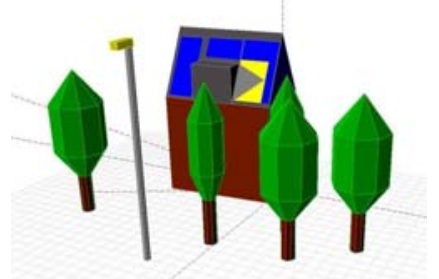

(c)

Fig. 8. Example hours from simulation for both the standard module system, (a) and (c), and for the Tessera system (b) and (d). (a) and (b) are from January, and (c) and (d) are March. The grey areas represent the linear shading caused by the shading objects. The yellow areas represent the PV energy that is lost over and above the linear shade.

The details of the percentage and watt.hour losses for these two hours are presented in TABLE III. The Tessera module system shows a $24 \%$ gain over the standard system for the January morning where the light pole can be seen casting a shadow across nearly all the modules on the left side of the roof. In this instance the standard system loses almost $1 \mathrm{kWh}$, while the Tessera system loses only half that amount. And for the dormer shade in the March afternoon the Tessera system gives a $17.5 \%$ gain.
TABLE III

HOURLY LOSSES AND GAINS

\begin{tabular}{|c|c|c|c|}
\hline $\begin{array}{c}\text { Date and } \\
\text { time }\end{array}$ & $\begin{array}{c}\text { Standard } \\
\text { system } \\
\text { loss } \\
\%,(\mathrm{Wh})\end{array}$ & $\begin{array}{c}\text { Tessera } \\
\text { system } \\
\text { loss } \\
\%,(\mathrm{Wh})\end{array}$ & $\begin{array}{c}\text { Tessera } \\
\text { Gain } \\
(\%)\end{array}$ \\
\hline $\begin{array}{c}11^{\text {th }} \text { Jan. } \\
11: 00-12: 00\end{array}$ & $32.4,(995)$ & $16.6,(511)$ & 24 \\
\hline $\begin{array}{c}24^{\text {th }} \text { March. } \\
16: 00-17: 00\end{array}$ & $27.4,(476)$ & $14.9(256)$ & 17.5 \\
\hline
\end{tabular}

\section{CONCLUSIONS AND OUTLOOK}

A new shade robust module, the Tessera module has been designed and prototypes have been manufactured. The module uses a combination of series and parallel connections to substantially reduce the effect of shading and allows scalability. The near constant maximum power point voltage operation also reduces the possibility of inverter loss due to low voltages. The modules can be manufactured by adapting the electrical lay-out and creating shade independent blocks inside the module using in-laminate diodes. When using back contact solar cells and modules, this is possible without additional manufacturing costs.

Through shade performance measurement and annual yield calculation we have shown the shade linearity and energy yield benefits of this module and system design. In our test cases the Tessera module shows up to $92 \%$ shade linearity compared to a maximum of $66 \%$ for a standard module. For particular hours a $24 \%$ energy gain can be obtained compared to standard modules.

For systems where shade is not an issue the annual yield is expected to be the same as for a standard system. However, in cases where shade is present a substantial annual yield gain can be expected, calculations have shown the annual yield gain of the Tessera module to be $4 \%$.

The diodes in the Tessera module only reach $40^{\circ} \mathrm{C}$, compared to $>130^{\circ} \mathrm{C}$ for conventional diodes. This is important for application in the built environment, as entire roof areas can be used. This can also help accelerate the BIPV market.

Further developments will include: the manufacture and performance monitoring of full-size Tessera modules, the development of dedicated micro-inverters and a detailed costbenefit analysis of the system.

\section{ACKNOWLEDGEMENT}

This work is partly financed through the INHYPE project with financing from the Dutch Ministry of Economic Affairs (TKI Solar Energy, file nr TEZ0114002) 


\section{REFERENCES}

[1] M. W. P. E. Lamers et al, “17.9\% Metal-Wrap-Through mc-Si cells resulting in module efficiency of $17.0 \%$ ", Progress in Photovoltaics, vol 20 (1), 62-73, (2012).

[2] http://sargosis.com/articles/science/how-shade-affects-a-solararray/

[3] K. Sinapis et al, "Outdoor characterization of three PV architectures under clear and shaded conditions", $29^{\text {th }}$ European Photovoltaic Solar Energy Conference and Exhibition, 2014

[4] A.J. Carr et al, "A High Voltage MWT Module with Improved Shadow Performance", 40th IEEE Photovoltaic Specialist Conference, 2014, p. 2685

[5] W. Eerenstein et al, "Climate chamber test results of MWT back contact modules", 25th European Photovoltaic Solar Energy Conference and Exhibition, 2010, $\mathrm{p} \mathrm{x}$.

[6] Patent "Assembly of photo-voltaic cells", M.J. Jansen, A.J Carr, E.E. Bende, J.A.M. van Roosmalen, B. Heurtault, N. Guillevin. Patent nr P102235NL00

[7] M. de Bruijne et al, "Shade performance of a novel high-voltage back contact module", 29th European Photovoltaic Solar Energy Conference and Exhibition, 2014, p x

[8] J. Bakker and A.B. Verschoor, "Method and device for producing a solar panel using a carrier", US patent 8753915 , 2014

[9] M.J. Jansen et al, ECN patent pending 2015

[10] PVsyst V6.10, PV "Study of Photovoltaic Systems". PVsyst SA, Satigny, Switzerland. www.pvsyst.com 